\title{
Impact of Efficient Credit Management on Profitability of Commercial Banks in Sierra Leone
}

\author{
Daniel B. Kaitibi1 ${ }^{*}$, Ezekiel T. J. Ganawah ${ }^{2}$, Musa A. Yokie, Muneer Jalloh ${ }^{1}$, Bashiru M. Koroma ${ }^{2}$ \\ ${ }^{1}$ Department of Physics and Computer Science, School of Technology, Njala University, Main Campus, \\ Njala, Sierra Leone \\ ${ }^{2}$ School of Postgraduate Studies, Njala University, Freetown, Sierra Leone \\ Email: *dkaitibi@njala.edu.sl
}

How to cite this paper: Kaitibi, D.B., Ganawah, E.T.J., Yokie, M.A., Jalloh, M. and Koroma, B.M. (2018) Impact of Efficient Credit Management on Profitability of Commercial Banks in Sierra Leone. Open Journal of Business and Management, 6, 139-150.

https://doi.org/10.4236/ojbm.2018.61009

Received: July 28, 2017

Accepted: January 21, 2018

Published: January 24, 2018

Copyright $(9) 2018$ by authors and Scientific Research Publishing Inc. This work is licensed under the Creative Commons Attribution International License (CC BY 4.0).

http://creativecommons.org/licenses/by/4.0/

\begin{abstract}
The main objective of this research was to critically assess the impact of efficient credit management on profitability of commercial banks in Sierra Leone. For this purpose, the Rokel Commercial Bank was selected as a case study. Collection of secondary data was mainly from the five years financial statements of the bank for period 2010 to 2014, and annual reports of the bank. The analysis of the data was quantitatively as well as qualitatively done using ratios analysis and charts. Results show that profitability of commercial banks in Sierra Leone is significantly influenced by the efficiency of credit management. The findings from this study noted the need for banks in Sierra Leone to have in place a good credit policy in order to improve their profitability.
\end{abstract}

\section{Keywords}

Profitability, Credit Management, Banks, Sierra Leone

\section{Introduction}

Credit creation has proved to be an important function of commercial banks since it is the main source of commercial banks' internally generated revenue [1]. From the commercial perspective, credit involves giving out resources obtained from depositors held in their customers' accounts, to another party at an interest rate higher than what they pay to suppliers of funds with the aim of maximizing profit [2] [3].

This piece presents a critical analysis of the impact of efficient credit management on commercial banks' profitability, as a way of achieving their broader 
organizational goals. As such, an efficient credit management policy of any bank determines the achievement of its goal. Therefore, the use of working capital techniques, ratio analysis and other forms of analysis such as tables and charts, were useful tools for obtaining results being utilized to give adequate recommendations for future researches.

Credit creation is considered one of the oldest and most sensitive functions of the commercial banks [4]. Thus, Credit Management by commercial banks is of great importance to the general economic growth and development of any country as it allows funds to be available through the credit creation to areas such as mining, agriculture, industries, manufacturing, etc. [4] [5] [6]. This will have positive impact on the level of employment, development and economic growth and per-capita income [6] [7] [8].

The Rokel Commercial Bank Ltd. is sighted as case studies as it is one of the first indigenous banks. In Sierra Leone, banks and banking services were foreign based until the establishment of the Central Bank of Sierra Leone in the year 1964. This eventually led to the formation of Rokel Commercial Bank, which was established in 1917 as Barclay Bank DCO with 100\% shares own by the British [9]. To established indigenous ownership, Barclays Bank DCO incorporated local interest and offered $25 \%$ of shares to Sierra Leoneans and renamed the bank as the Barclays Bank of Sierra Leone Limited in 1971. Due to the eleven year civil war the parent branch Barclays Bank PLC withdrew its shares from Sierra Leone branch. The ownership status was immediately changed and management changed the name to Rokel Commercial Bank with $51 \%$ of its shares own by the government of Sierra Leone [9] [10].

\section{Background to the Study}

Banks are financial institutions that are established for lending, borrowing, issuing, exchanging, taking deposits, safeguarding or handling money under the laws and guidelines of a respective country [11] [12]. Among their activities, credit provision is the main product which banks provide to potential business entrepreneurs as a main source of generating income. The importance of strong credit management for building quality loan portfolio is of paramount importance to robust performance of commercial banks as well as the overall economy [13].

While providing credit as a main source of generating income, banks take into account many considerations as a factor of credit management, which helps them to minimize the risk of default that results in financial distress and bankruptcy. This is due to the reason that while banks provide credit they are exposed to risk of default (risk of interest and principal repayment) which need to be managed effectively to acquire the required level of loan growth and performance [13]. The types and degree of risks to which banks are exposed depends upon a number of factors such as its size, complexity of the business activities, volume etc. It is believed that generally banks face Credit, Market, Liquidity, 
Operational, Compliance/legal/regulatory and reputation risks among which credit risk is known to have the adverse impact on profitability and growth [14]. Hence, the success of most commercial banks lies on the achievements in credit management mitigating risk to the acceptable level. Credit risk management has always been in the vicinity of concern throughout the world.

Credit Management is one of the core functions of every Commercial Bank. As banks heavily rely on this activity for revenue generation, efficient credit management is therefore vital to the profitability of every commercial bank. Hence, conducting a research in this area has brought out a number of issues that probably have served as hindrance to increase profit maximization in a number of financial institutions. Credit management (its creation and control) is therefore the process of controlling and collecting payments from customers. This is the function within a bank or company to control credit policies that will improve revenues and reduce financial risk.

Credit management in commercial banks in Sierra Leone is being regulated to a certain extent by the Central Bank of Sierra Leone which sets the requirements the bank needs to fulfill before being granted a license to start operations. These requirements include the following: a business plan, information on the proposed license institution and minimum paid-up capital among others [14] [15].

Table 1 below shows the capital requirement that any institution should maintain in order to operate as a bank in Sierra Leone. This minimum capital requirement is what comes from the shareholders as capital contribution, out of which, and savings from people with surplus funds is the business of credit management.

The formal credit decision can be made individually or by committee, depending on a bank's organizational structure. This structure varies with a bank's size, number of employees, and type of loans handled. A bank's Board of Directors normally has the final say on which loans are approved. Typically, each

Table 1. Minimum paid up capital.

\begin{tabular}{cc}
\hline YEAR & CAPITAL REQUIREMENT \\
\hline 2007 & Le9 billion (or its equivalent in United States Dollars) \\
2008 & Le12 billion (or its equivalent in United States Dollars) \\
2009 & Le15 billion (or its equivalent in United States Dollars) \\
2010 & Le18 billion (or its equivalent in United States Dollars) \\
2011 & Le21 billion (or its equivalent in United States Dollars) \\
2012 & Le24 billion (or its equivalent in United States Dollars) \\
2013 & Le27 billion (or its equivalent in United States Dollars) \\
2014 & Le30 billion (or its equivalent in United States Dollars)
\end{tabular}

Source: Revised commercial banks license requirement; Banking supervision department, Bank of Sierra Leone. 
lending officer has independent authority to approve loans up to some fixed Leone amount. This collective responsibility of commercial bank's employees is what make up for the bank's profitability couple with effective and efficient credit management tools in place.

\section{Data Collection Methods}

\subsection{Research Design}

This is historical and analytical research based on a case study approach. A cross sectional study design was used where both the quantitative and qualitative data were collected from Years 2010 to 2014 (inclusive), to ascertain the relationship between efficient credit management and profitability. The Quantitative method enabled me to summarise several information and facilitate comparisons across different years using ratios, statistical charts and tables for further analysis. Also, qualitative data was obtained using questionnaires and interview conducted within the various departments of the bank.

The justification of this methodology stems from the need to establish and implement an effective credit management policy, a set of controls which were then applied to evaluate the extent to which best practice can be adopted. The motivation for doing qualitative research, as well as quantitative research, comes from the observation that, if there is one thing which distinguishes one bank from another, it is the ability of such bank to create credit and manage such credits effectively.

\subsection{Population and Sample}

The population of the Rokel Commercial Bank Ltd total to three hundred and thirty-six (336) employees spread into various branches and departments. This target population was used to carry out the investigation.

Given the quest for a proportional representation, a stratified random sampling was assumed to provide more efficient sample. Considering this fact, the study was done on 135 respondents (about $40 \%$ of the total population) who are staff of the Rokel Commercial Bank from various branches and departments including credit control department, finance department, Human Resource department and some senior management staff. Special consideration is given to the knowledge and skills of the respondents in relation to the variables under study.

\subsection{Research Instrumentation}

This exercise was set out to achieve the objectives of the research by deriving a set of established criteria which outline the requirement of an effective credit management function. The instrumentation looked at the methods used in collecting data, and for this purpose is categorized into two: quantitative and qualitative data [16]. The methods use are Questionnaires, Interview, Desk Research (for secondary data), and personal interface with management. The data col- 
lected is analysed using ratios like profitability, liquidity, solvency and turnover. Analytical notes and graphs are used for presentation of findings.

\subsection{Data Collection Procedure}

For the purpose of this study, both primary and secondary data were used. Interviews were conducted and questionnaires administered to collect primary data. This helped to address the research questions more specifically or to concentrate more on the topic itself.

Secondary data was collected by desk research using financial statements, text books, journals, files, reports, directives, manuals and bulletins of the bank. The Internet was another major source of secondary data.

\subsection{Method of Data Analysis}

The collected data was edited, sorted and codded in readiness for analysis. In order to establish the relationships between efficient credit management and profitability, the bank's financial statements are analyzed using calculated ratios and do compare the different financial years. A preparatory list of tables relating to financial statements relevant to the bank's operations, and effective credit management functions are drawn up and modified as analysis proceeds and new ideas and concepts emerge.

Accounting ratios calculated on a systematic basis allow trends to emerge and throw into relief the significance of changes indicated by the analysis of current events which should be reflected in a bank's credit policy (Table 2). Since the future is unclear, past financial performance of the bank reflected by ratios analysis was relied on greatly to adjust the bank's credit policy for the future. Though they are the first order condition necessary, it must be emphasised that ratios on their own are not sufficient providers of information about a bank's credit policy.

Table 2. Table of list-Key Ratios.

\begin{tabular}{ccc}
\hline Ratios & Meaning & Definition \\
\hline Profitability & Asset Yield (AY) & AY = Interest/Asset \\
& Profit Margin (PM) & PM $=($ Profit/Turnover $) \times 100$ \\
Return on Equity (ROE) & ROE $=$ PM $\times$ AY $\times$ LF \\
Liquidity & Liquid Asset Ratio (LAR) & LAR $=($ Total Cash/Asset $) \times 100$ \\
Loan to Deposit Ratio (LDR) & LDR = (Loan/Deposit) $\times 100$ \\
Interest Rate Risk & Debt Ratio (DR) & DR = Debt/Equity \\
Management & Asset Interest Yield (AIY) & AIY = IR/A \\
& Break Even Yield (BEY) & BEY = IE/A \\
& Net Interest Margin (NIM) & NIM = NII/A \\
& Loan Loss Provision (LLP) & LLP = Total Loan Loss/Total Loan' \\
Credit Risk Management & Risk Adjusted Margin (RAM) & RAM = NI + OI - PRI/AA
\end{tabular}




\section{Finding: Results \& Discussions}

\subsection{Key Findings}

The Rokel Bank (our case study) is the primary bank in Sierra Leone bent on providing loans for business activities in the retail sector, particularly the import on which the local economy currently depends. The bank has implemented cutting edge technology and is constantly launching new products and services. It also offers ATM and VISA cards which can be use worldwide. Above all, the bank partners with the international finance corporation, the Africa Development Bank and other international funders to provide extended credit line and long-term lending.

From the analysis and interpretations of the data obtained in this research for the period under review (i.e. year 2010 to 2014), the following major findings were made about Rokel Commercial Bank:

On $17^{\text {th }}$ September 1999, Barclays Bank Plc. which was the majority shareholder (60\% shares) withdrew from its operations in Sierra Leone after extensive discussions with the Government. The Bank after consultations with the Government was renamed Rokel Commercial Bank (Sierra Leone) Limited. The Government of Sierra Leone held 51\% shares, $40 \%$ shares owned by institutions, private bodies, organizations, individuals and $9 \%$ owned by staff under the employee share incentive scheme [17].

The shareholding structure of the bank changed when at its Annual General Meeting held on $29^{\text {th }}$ October 2014, it was resolved that the authorised share capital be increased from 30,000,000,000 ordinary shares of Le1.00 each to $60,000,000,000$ shares with the same nominal value. The government which is the majority shareholder represented by the National Commission for Privatization, on $31^{\text {st }}$ December 2014, deposited Le60 billion for shares in a bid to recapitalize the bank. This acquisition at the price of Le5.5 per share, increased the shareholding of the majority shareholder to $65.02 \%$ of the bank's issue share capital [17].

In addition to this, the bank accepts deposits from the public, out of which advances are made to borrowers. Principally, the bank is engaged in retail, corporate and commercial banking services in Sierra Leone and operates in thirteen branches in addition to its head office. Six of these branches are at various locations in the provinces.

Giving out advances is thus an important part of the bank's operations. The deposits made by customers form a major source of income for the bank by giving it out as advances. The lending criteria for the bank include the purpose for which the loan is needed, the repayment schedule and procedures, and the availability of collateral security.

The lending activities of the bank centre on the following economic sectors: agriculture; forestry and fishing; manufacturing; construction; commerce and finance; transport; information and communication; services; miscellaneous; electricity and water. A significant proportion of the advances given out have 
been going to the commerce and finance sector of the economy.

\subsection{Analysis of Key Ratios}

The table below defines key ratios used to analyze and interpret key findings from the data obtained:

\subsection{Profitability Ratios}

The position of the bank's profitability has been deplorable in the last two years of the period under review. This can evidently be linked to lapses in the credit management policy, given the increase rate of default. For instance, there was a semi-freeze on lending throughout 2014; and some non-performing debts which were not attracting interest resulting in a drop in interest income from Le55 billion in 2013 to Le32 billion in 2014. The average yield for 91 days Treasury bill declined from $3.39 \%$ to $2.36 \%$ (2013); the 182 days Treasury bills rate from $7.50 \%$ to $2.83 \%$ (2013), and 364 days Treasury bill rate from $9.47 \%$ to $5.12 \%$ (2013). The effect of these shifts in rates was a drop in interest income as shown in the graph:

In Figure 1, the Bank's prime lending rate remained constant at $18 \%$. Even though deposits from customers grew by 7\% from Le609 billion (2013) to Le650 billion (2014), the bank's financial statements shows an underutilization of capital employed (net asset) in generating more sales to increase profit (Figure 1).

Also, it is observed in Figure 1, that the asset yield (AY) ratios are falling yearly, and financial leverage shows a negative ratio of $-16 \%$ in 2013 . Although there is no benchmark, this is not a very efficient use of the bank's capital employed as the low ratios signify an underutilization of the investment in assets (Figure 1).

\subsection{Liquidity/Solvency}

From Figure 2, it can deduce the trends in liquidity management ratios during the period under review. The liquid asset ratios (LAR) have inconsistently changed over the years which saw and increase from 24\% in 2010 to $33 \%$ in 2011 and a fall to $30 \%$ in 2012. Again, we saw a rise to a $41 \%$ in 2013 and a fall to $38 \%$ in 2014. This simply informs us that the Rokel Bank is consistently following a low liquidity trend throughout the period.

Also, during this period the loan to deposit ratios (LDR) decreased consistently to $18 \%$ in 2014 from $63 \%$ in 2010 , which is the highest figure for all the years under review. The liquidity management ratios seem to indicate that the bank in particular is parking funds in Treasury Bills and other liquid assets, which may be due to lack of demand for credit as indicated by the $42 \%$ drop from 2012 to 2013 in loan and advances to customers. A further 29\% drop in 2014 was as a result of a semi freeze on lending throughout the year. One would probably see a change in these ratios once loan demand picks up (Figure 2).

Again the debt ratio (DR) position of the bank signifies that the bank's solvency position is shaky. Although the bank's business of intermediation between 


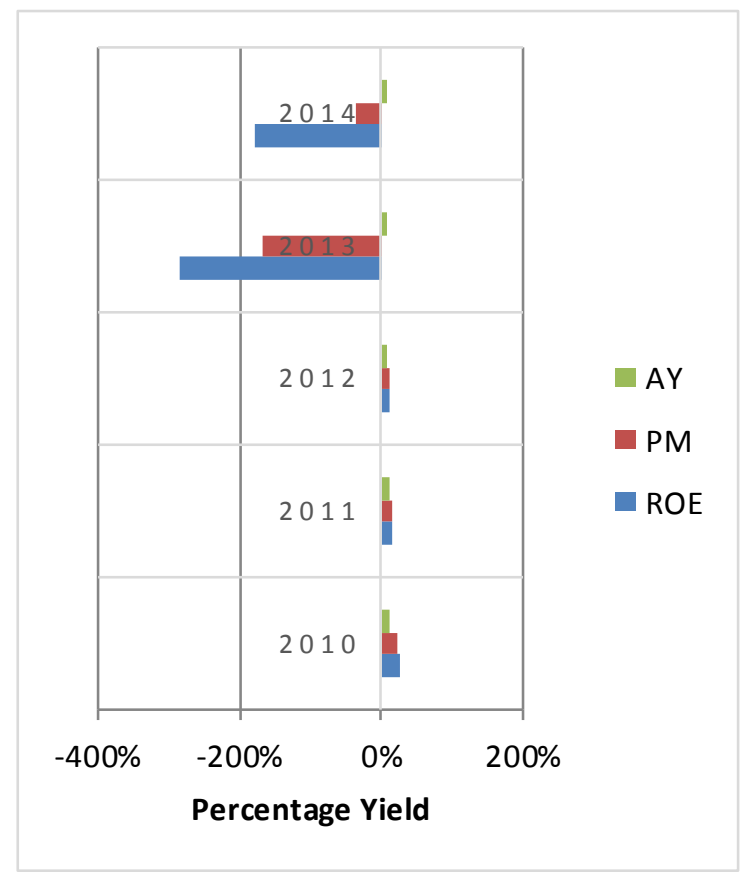

Figure 1. Profitability ratio analysis.

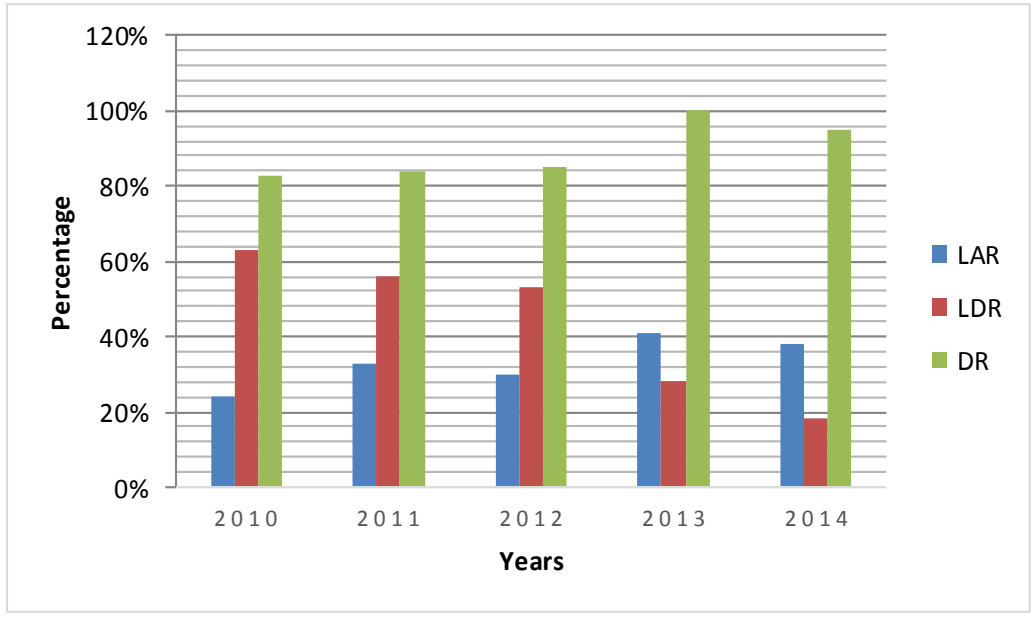

Figure 2. Liquidity management ratios.

deficit and surplus units put it in a position to have a high debt ratio, it must to a greater extent try to reduce or remedy this situation by making profitable investment (e.g. securities, bonds etc.) which will bring in more funds or resources and reduce the bank's risk (Figure 2). As a result of high debt ratio, the bank's credit worthiness is unstable as creditors or lenders are in no way willing to let go of more funds to the bank.

\subsection{Interest Rate Risk Management Ratios}

In Figure 3, Comparing the interest rate management ratios with the earlier period, there is an increase from $10 \%$ in 2010 to $12 \%$ in 2011 and a decline 


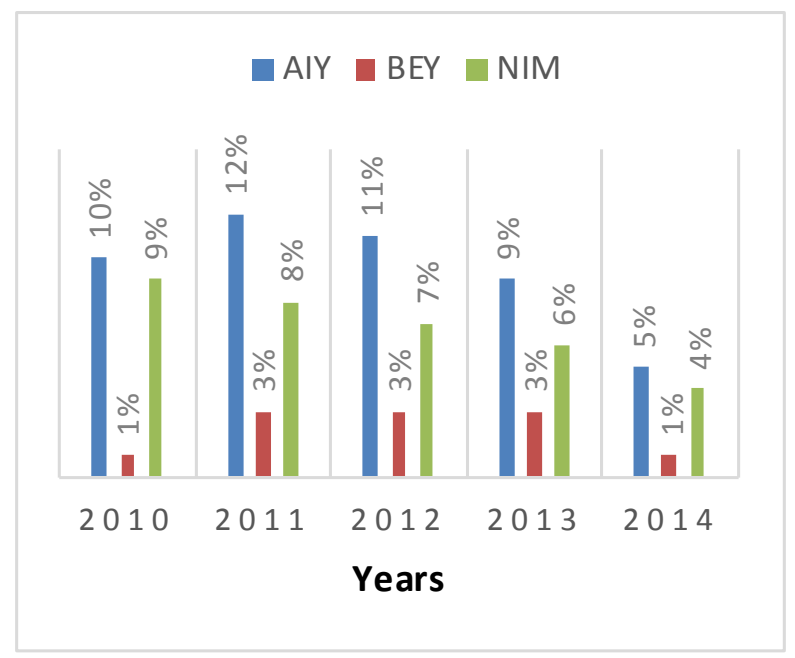

Figure 3. Interest rate management ratio.

thereafter in Asset Interest Yield (AIY) as well as a one-step increase in Break Even Yield (BEY). Asset Interest Yield declined from around 12\% in 2011 to 5\% in 2014, while Break Even Yield rises from 1\% in 2010 to 3\% following unto year 2013, and then a drop to 1\% in 2014. Since the decline in Asset Interest Yield has been in general more than the rise in Break Even Yield the net impact is a fall in Net Interest Margins (NIM) from 9\% in year 2010 to $4 \%$ in year 2014. The change in Asset Yield, Break Even Yield and Net Interest Margin has to be viewed in the light of a general fluctuation in interest rates in the Sierra Leone economy (Figure 3). These ratios indicate that Rokel commercial banks could be able, in future years, to manage and overcome the interest rate risk created in an event there is a steady increase in interest rates

\subsection{Credit Risk Management}

In Figure 4, the trend in credit risk management ratios indicate that, during the five years period the bank shows fluctuation in Loan Loss Provisions (LLP) for improvement in credit quality. The performance of the bank in terms of Risk Adjusted Margin (RAM) has in general fallen, indicating poor management of assets and hence the risk management system of the bank (Figure 4).

RAM also shows what is available to meet the non-interest expenses (e.g. staff and administration expenses) and profit expectations of the shareholders (Figure 4). Improving asset quality is definitely an important task ahead of the banks as it has pivotal role in the credit risk management process.

Finally, aside from the fierce competition faced by the bank, the Sierra Leone economy itself was affected adversely by two major shocks in 2014; the unexpected outbreak of the Ebola virus and the unexpected drop in the price of Iron Ore both of which weakened the economic growth potential of the country. The reaping effect is that the bank posted a loss before tax of Le22 billion, the second time the bank is reporting a loss in its Fifteen years history. 


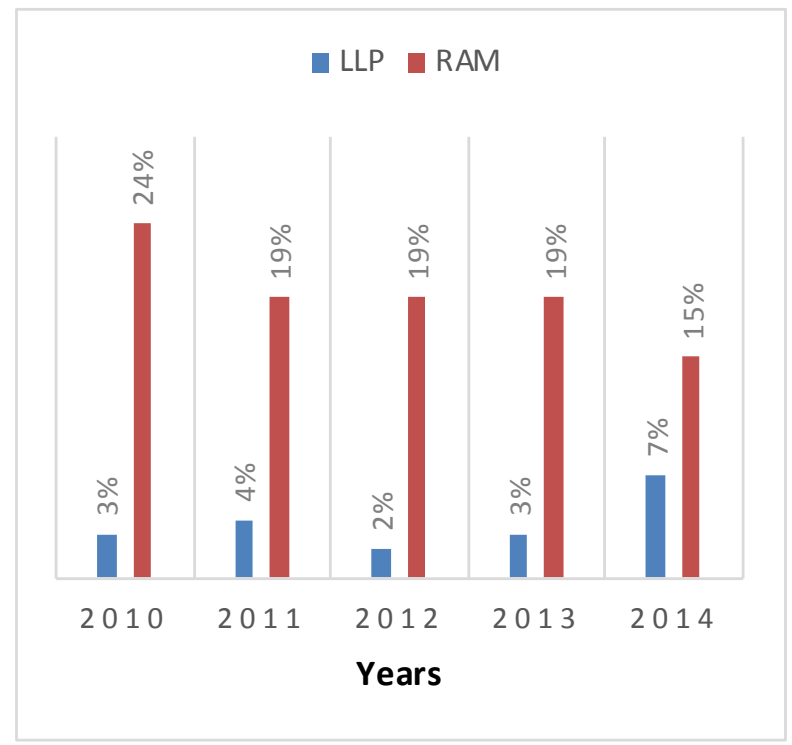

Figure 4. Credit risk management ratio.

\section{Conclusions}

The research questions as stated earlier were either negated or affirmed. The findings from the data collected, analysed and interpreted, one can validly state that the credit management policy adopted by Rokel Commercial Bank for the period under review is inefficient in achieving its organisational goals, as shown by the continuous decline in profitability.

Notwithstanding that, it could be noted that the credit management system of the bank have had room to improve its efficiency in terms of the amount of advances given out thereby impacting greatly on profitability. Though this was done by giving preference to particular sectors, the distribution was becoming more equitable with time. The agricultural sector which is considered the back bone of the economy is gaining gradual recognition.

Credit management is undoubtedly the heart of banking business in the country. Bank credit management is influenced by three factors namely regulators, institutional constraints, and macroeconomic policies. Bank business is perhaps the most regulated of all the businesses in Sierra Leone.

In effect, therefore, Rokel commercial bank has management skills which appear to benefit the bank's overall performance. Optional branch network, lending opportunities, staff strength are all factors considered by Rokel Commercial Bank S/L Ltd in their credit management.

From the findings of this study, the following recommendations would be worthwhile:

Amidst fierce competition for limited available resource in the banking sector especially with the influx of Nigeria banks, there is need for improvement on products and facilities offered, and especially for development of entrepreneurial initiatives and skills. This need is more appropriate in the small-scale sectors of the manufacturing and agricultural industries. 
The bank should consider creating more branches across the country, and especially in the Provinces with increased mining companies. There should also be branches in the chiefdom headquarters in order to extend to all the no banked areas of the country.

There is high necessity to reduce the bank's operating costs and substantially improve the productivity of the bank's physical, financial and human resources. In order to do this, there should be a planned of action programme for re-organising the bank's operating structure, staffing levels, technology control systems and operating procedures.

There should also be a segregation of duties among those who transact business, control receipts and custody of security, transfer and receive funds and control accounting records for advances made by the bank to its customers.

The general recommendation for the bank vis-à-vis the efficiency of its credit management is that: the bank credit should be productive, projects and ventures with low capital intensity should be accorded preference. Likewise, non-performing loans and advances build-up without adding to profitability/revenue, should be curtailed.

Preference should be giving to economic sectors that contribute more to domestic growth. It has been found that commerce and finance sector takes a huge proportion of the advance portfolio. This is not good for the Sierra Leone economy where foreigners spearhead the commerce. It is therefore prudent for more priority to be given to the agriculture, forestry and fishing sector.

It is recommended for future researchers to widen the scope say, ten years and to include more banks.

The analysis of financial statements using individual ratios in isolation has its limitations giving conclusive information in the financial performance of the bank, it is necessary therefore, to combine different financial ratios into a meaningful statistical model as an addition to the analysis.

\section{References}

[1] Jens, B.-A., Lars, R. and Morten, S. (2014) Money, Credit and Banking. Monetary Review. 3rd Edition, Danmarks National Bank, Danmarks, 65-81.

[2] Achou, T.F. and Tengu, N.C. (2008) Bank Performance and Credit Risk Management. Diva Portal, Hisborn.

[3] Charles, O. and Kenneth, O.U. (2013) Impact of Credit Risk Management and Capital Adequacy on the Financial Performance of Commercial Banks in Nigeria. Globalresearch, Lagos.

[4] Small-Business-Briefs/Small-Business-Brief-Credit-Management (2016). http://www.smallbusiness.wa.gov.au/assets/Small-Business-Briefs/small-business-br ief-credit-management.pdf

[5] Abedi, S. (2000) Highway to Success, Credit Management Journal. http://leatherspinters.com

[6] Murthy, Y.R. (2010) Study on Financial Ratios of Major Commercial Banks. College of Banking and Financial Studies, Sultanate of Oman.

[7] Westerfield, R., Ross, S.A. and Jordan, B.D (2008) Fundamentals of Corporate Fi- 
nance. Tata McGraw-Hill Education, New York.

[8] Michael, B.W. (2011) Credit Management Policy and Profitability of Commercial Bank, a Case Study of Housing Finance Bank (HFB). Makerere University, Kampala.

[9] West African Bankers Association (2016). http://waba-abao.org

[10] History of Rokel Commercial Bank (2016). https://rokelbank.sl/about-us/

[11] Association of Certified Chartered Accountant, Financial Management F9 (2014) Financial Management. BPP Publishing, London.

[12] Association of Certified Chartered Accountant, Performance Management F5 (2010) Performance Management. Emile Woolf Publishing, London.

[13] Mirach, H. (2010) Credit Management (A Case Study of Wegagen Bank Share Company in Tigray Region). College of Business \& Economics, Mekelle University, Mekelle.

[14] N'jai, L. (2000) An Assessment of the Impact of Credit Management of the Commercial Viability of Telecommunications Industry. Unpublished Dissertation, IPAM-USL, Sierra Leone.

[15] Sannoh, A. (2009) The Effectiveness and Efficiency of Credit Creation Adopted by Commercial Banks in Sierra Leone. Unpublished Dissertation, IPAM-USL, Sierra Leone.

[16] Crawshaw, J. and Chambers, J. (1985) A Concise Course in A-level Statistics. Nelson Thornes, London.

[17] Rokel Commercial Bank (2015) Background to Rokel Commercial. http://www.europeantimes.com/sector/finance-consulting/rokel-bank 